\title{
The Investment in Fixed Assets Before and After the Global Financial Crisis (Empirical Study for Industry and Investment Sector in Palestine Stock Exchange)
}

\author{
Tamer Bahjat Sabri ${ }^{1}$ \\ ${ }^{1}$ Department of Computerized Financing and Banking, The College of Business and Economics, Palestine Technical \\ University, Kadoorie, Tulkarm, Palestine \\ Correspondence: Tamer Bahjat Sabri, Associate Professor, Department of Computerized Financing and Banking, \\ The College of Business and Economics, Palestine Technical University, Kadoorie, Tulkarm, Palestine.
}

Received: January 2, 2021

Accepted: February 17, 2021

Online Published: March 18, 2021

doi:10.5430/ijfr.v12n4p52

URL: https://doi.org/10.5430/ijfr.v12n4p52

\begin{abstract}
This paper seeks to shed light on investment in fixed assets before and after the financial crisis that took place in 2008 and compare the two periods together in the sectors of industry and investment in Palestine Stock Exchange. The period between 2005 - 2007 was chosen to represent to the pre-crisis time and the period between $2010-2012$ was chosen to represent the post-crisis time. The population of the study consists of fifteen organizations from both sectors. To test the hypothesis of the study, the independent samples T-test was employed.

The average ratio of fixed assets to the total assets of industry and investment rose from $56.2 \%$ before the crisis to $58.5 \%$ after the crisis. As for the hypotheses of the study, the findings showed no difference except for the seventh hypothesis. There was a statically significant difference in the ratio of fixed assets to equity between the listed companies that a high return on assets and those that have a low return.
\end{abstract}

Keywords: financial crisis, long term investment, fixed assets to total assets, fixed assets to equity ratio, independent samples t-test

\section{JEL Classification Codes: G20; G21; G22}

\section{Introduction}

Expenditure on fixed assets is a commitment to take on annual fixed burdens. These fixed burdens are not by the volume of production as projects are to take such burdens on whether they are productive or unproductive. This problem arises in times of recession, so the management of fixed assets is exceptionally significant.

Moreover, investment in a certain fixed asset affects the facility on the long run as the decision of buying a certain machine decides the kind of production, and the quality level. Also, selling a fixed asset is not an easy task as well as it is not easy to use that fixed asset for a different job. Fixed assets are in danger of technological and technical obsolesce as new more efficient and less costly machinery come out every year. Therefore, maintaining the old machinery, despite being in good condition, gets uneconomical. In light of these justifications, investment in these assets is of great importance especially in those organizations in which fixed assets represent most total assets (Lazar and lazar, 2012).

The Palestinian economy is one of the emerging economies structure wise. It is characterized by many characteristics whose components are different due to several factors concerning the structure and the functional nature as the Palestinian economy was complementary of the Israeli economy. According to (TBH Sabri, KMH Sweis, 2016) recommended that banks should not only focus on economic and legal issues but also on social ones. The Palestinian National authority has attempted since its arrival to put foundational mechanisms to shape the institutional and economic structures in coordination with many countries. It activated the role of production sectors through setting monetary, financial, industrial, agricultural and economic programs. It also made necessary economic laws. Consequentially, the Palestinian economy has been shaped by complementary economic structures (Abu Alqumssan, 2005). Despite these statistical results that were reached in that period, there were unreal in terms of the economic 
core. That is, those results did not constitute a strategic foundation for economic construction and facing the international financial crises.

Among the components of the Palestinian economy are the listed companies in Palestine Exchange among of which are the sectors of industry and investment. Fixed assets constitute a high percentage of these firms' budgets. Prior to the international financial crisis, these fixed assets were about $56 \%$ of the total assets, whereas after the crisis, they were $58.5 \%$. This study is meant to help organizations manage their asses in times of crises efficiently which in turn helps raise profits. Thus, this boosts the growth of the Palestinian economy. This study attempts to answer the following questions:

1. Is there an average difference in the ratio of fixed assets to total assets between organizations with high return on assets and those with low return before and after the international crisis?

2. Is there an average difference in the ratio of fixed assets to total assets between the firms with high return on sales and those with low return on sales before and after the international crisis?

3. Is there an average difference in the ratio of fixed assets to shareholders equity between the firms with high return on assets and those with low return on assets before and after the international crisis?

4. Is there an average difference in the ratio of fixed assets to the shareholders equity between with high return on sales and those with low return before and after the crises?

\section{Review of Literature}

(Dong, et.al, 2012) aimed to investigate the debate of over-investment by studying the listed companies in China. They found that companies that have a higher level of fixed asset holding and overhead expenses, in China to be associated with lower risk-adjusted performance. While (Mohammadzadeh, et. al., 2014) aimed to determine the impact of Dividend Yield on investment in fixed assets. The stock market during 2003-2007 was selected .The results indicated the existence of a relationship between dividends and investments in fixed assets for active companies.

(Olatunji, and Adegbite, 2014) used Pearson correlation and regression analysis to analyse the relationship between net profit and independent variables (building, land or real estate leased buildings, fixtures and fitting, and investment in computers). The results showed that there is a statistically significant relationship between the dependent variable (net profit) and independent variables. The research of (Iqbal and Mati, 2013) aimed to find out the relationship between the profitability of the company and non-current assets. Multiple regression analysis was used to determine the nature of this relationship. The study concluded that there is a relationship between the profitability of the company and non-current assets.

On the contrary (Okwo, and Okelue 2012), aims to assess the impact of the company's investment in fixed assets on its operating profit margin. But the results showed that there was no relationship between the company's investment in fixed assets and its operating profit margin.

In another study, (Eriotis, et.al, 2014), aimed to investigate the relationship between the ratio of debt to shareholders' equity and profitability, taking into account the level of investment companies and the degree of competition. The results showed that companies prefer to compete with each other instead of participating, as well as the companies use investment in fixed assets as a strategic variable to affect profitability In their paper, (Çelikand and Boyacioğlu, 2013) aimed to determine the impact of investments in fixed capital on working capital management. According to the results of the regression analysis, it was demonstrated that there ineffective fixed assets on working capital management

Finally (Lazăr, and Lazăr, 2012) presented the development of key indicators in Romania after 1990 with particular emphasis on the 2008-2010 to highlight the negative impact of the global economic crisis which began at the end of 2008.

What distinguishes the study from previous studies is: this study attempts to answer Is there an average difference in the ratio of fixed assets to total assets between organizations with high return on assets and those with low return before and after the international crisis? And is there an average difference in the ratio of fixed assets to total assets between the firms with high return on sales and those with low return on sales before and after the international crisis? According to the researcher's knowledge, these goals have not been studied in previous research with the same methodology. 


\section{The Methodology}

\subsection{Data}

Data were collected from Palestine Exchange reports estimates annually, the study covers the pre crisis period 2005-2007and post crisis from 2009to2011. And use to analyse the data Statistical Package for the Social Sciences (SPSS).The study sample equal 15 company, includes two sectors: Industry Sector, Investment Sector.

\begin{tabular}{ll}
\hline 1 & Arab Company for Paints Products APC \\
\hline 2 & Palestine Poultry AZIZA \\
\hline 3 & Birzeit Pharmaceuticals BPC \\
\hline 4 & Golden Wheat Mills GMC \\
\hline 5 & Jerusalem Cigarette JCC \\
\hline 7 & Jerusalem Pharmaceuticals JPH \\
\hline 8 & Palestine Plastic Industries LADAEN \\
\hline 9 & The National Carton Industry NCI \\
\hline 10 & The Vegetable Oil Industries VOIC \\
\hline 11 & Arab Investors ARAB \\
\hline 12 & Jerusalem Real Estate Investment JREI \\
\hline 13 & Palestine Development \& Investment PADICO \\
\hline 15 & Palestine Investment \& Development PID \\
\hline
\end{tabular}

\subsection{Variables of the Study}

-Fixed assets to total assets ratio a measure of Measure the proportion of what constitutes fixed assets of total assets a high ratio $50 \%$ or higher, indicates an inefficient use of working capital which reduces or limit the companies' ability to respond to increased demand for products.

-Fixed assets to equity ratio or fixed assets to net worth ratio measures the proportion of what constitutes fixed assets from equity.

-Return on Asset is an indicator over the company's efficiency in the management of its assets to generate earnings.

-Sales on assets or Asset Turnover is an indicator Over the company's efficiency in the management of its assets to generate revenue.

\subsubsection{Calculation}

1. Calculationthe value of fixed assets to total assets ratio and then calculating Fixed assets to equity ratio.

2. Sort fixed assets to total assets according to the two variables Return on Asset Sales on assets and arranged from low to high.

3. Sort fixed assets to equity according to the two variables Return on Asset Sales on assets and arranged from low to high.

\subsection{Hypotheses}

The null Hypotheses -pre crisis

HO1: There is no difference in fixed assets to total assets ratio between Palestinian listed companies that have high return on asset and Palestinian listed companies that have low return on asset.

HO2: There is no difference in fixed assets to total assets ratio between Palestinian listed companies that have high sales on assets and Palestinian listed companies that have low sales on assets. 
HO3: There is no difference in fixed assets to equity ratio between Palestinian listed companies that have high return on asset and Palestinian listed companies that have low return on asset.

HO4: There is no difference in fixed assets to equity ratio between Palestinian listed companies that have high sales on assets and Palestinian listed companies that have low sales on assets.

And the same null Hypotheses for post crisis, Independent samples T-test, to test the hypotheses, we need to use the independent samples t-test to find the differences between the averages of two groups independent samples.

\section{Results-pre Crisis}

\subsection{Fixed Assets to Total Assets Ratio According to the Variable Return on Asset}

\subsubsection{Descriptive Statistics}

In this part will be displayed descriptive statistics such as mean, median, standard deviation, and the highest and lowest value. In Table 1 can be seen that the mean of Fixed assets to total assets ratio equal 56.2\% which is considered as higher than 50\%. Arguably indicates an inefficient use of working capital .And the maximum value equal 98\%, this value for Arab Investors ARAB in the Investment Sector. And the minimum value equal $12 \%$ for Jerusalem Cigarette JCC.

Table 1. Descriptive

\begin{tabular}{ll}
\hline & Statistic \\
\hline Mean & .5629 \\
\hline Std. Deviation & .23889 \\
\hline Minimum & .12 \\
\hline Maximum & .98 \\
\hline Skewness & -.191 \\
\hline Kurtosis & -.897 \\
\hline
\end{tabular}

\subsection{Normality Test}

Normality test was conducted using Kolmogorov-SmirnovandShapiro-Wilk the results in Table 2 showed that the data follow a normal distribution.

Table 2. Tests of normality

\begin{tabular}{lllllll}
\hline & \multicolumn{2}{l}{ Kolmogorov-Smirnov $^{\text {a }}$} & \multicolumn{4}{l}{ Shapiro-Wilk } \\
\cline { 2 - 7 } & Statistic & df & Sig. & Statistic & Df & Sig. \\
\hline $\begin{array}{l}\text { Fixed } \\
\text { assets }\end{array}$ & to & & & & \\
total & .121 & 42 & .129 & .960 & 42 & .149 \\
$\begin{array}{l}\text { assets } \\
\text { ratio }\end{array}$ & & & & & & \\
\hline
\end{tabular}

\subsection{Independent Samples Test}

The variable fixed assets to total assets ratio arrangement according to the variable Return on Asset from the least to the greatest .so configured two groups (the first group including 7 companies that have low return on assets, the second group including 7 companies that have high return on assets). From the Table 3 we notice that the mean of the first group equal $65.7 \%$ with a Standard deviation equal $18.7 \%$. The mean of the second group $46.7 \%$. 
Table 3. Group statistics

\begin{tabular}{lllll}
\hline & VAR00001 & $\mathrm{N}$ & Mean & Std. Deviation \\
\hline Fixed assetsto1.00 & 21 & .6579 & .18778 \\
\cline { 2 - 5 } totalassets ratio & 2.00 & 21 & .4679 & .25056 \\
\hline
\end{tabular}

Table 4 shows that the value of independent samples Levene's Test is significant at $5 \%$ level.

Table 4. Independent samples test

\begin{tabular}{|c|c|c|c|c|c|c|c|c|c|}
\hline \multicolumn{6}{|c|}{ t-test for Equality of Means } & \multicolumn{2}{|c|}{$\begin{array}{l}\text { Levene's Test } \\
\text { for Equality of } \\
\text { Variances }\end{array}$} & & \\
\hline $\begin{array}{l}95 \% \text { Confidence } \\
\text { Interval of the } \\
\text { Difference }\end{array}$ & \multirow{2}{*}{$\begin{array}{l}\text { Std. Error } \\
\text { Difference }\end{array}$} & \multirow{2}{*}{$\begin{array}{l}\text { Mean } \\
\text { Difference }\end{array}$} & \multirow{2}{*}{$\begin{array}{l}\text { Sig. } \\
\text { (2-tailed) }\end{array}$} & \multirow[b]{2}{*}{$\mathrm{df}$} & \multirow[b]{2}{*}{$\mathrm{T}$} & \multirow[b]{2}{*}{ Sig. } & \multirow[b]{2}{*}{$\mathrm{F}$} & & \\
\hline Lower & & & & & & & & & \\
\hline $0.32811 \quad 0.05193$ & 0.06833 & 0.19002 & 0.008 & 40 & 2.781 & 0.047 & 4.198 & $\begin{array}{l}\text { Equal } \\
\text { variances } \\
\text { assumed }\end{array}$ & \multirow{2}{*}{$\begin{array}{l}\text { Fixed } \\
\text { assets } \\
\text { to } \\
\text { total } \\
\text { assets } \\
\text { ratio }\end{array}$} \\
\hline $0.32845 \quad 0.05159$ & 0.06833 & 0.19002 & 0.008 & 37.079 & 2.781 & & & $\begin{array}{l}\text { Equal } \\
\text { variances } \\
\text { not } \\
\text { assumed }\end{array}$ & \\
\hline
\end{tabular}

So we reject the null hypothesis and accept the alternative hypothesis.so there is difference in fixed assets to total assets ratio between Palestinian listed companies that have high return on asset and Palestinian listed companies that have low return on asset.

\subsection{Fixed Assets to Total Assets Ratio According to the Variable Sales on Asset}

The variable fixed assets to total assets ratio arrangement according to the variable sales on Asset from the least to the greatest. So configured two groups (the first group including 7 companies that have low sales on Asset, the second group including 7 companies that have high sales on Asset). From the Table 5 we notice that the mean of the first group equal $71.7 \%$ with a Standard deviation equal $17.4 \%$. The mean of the second group $42.1 \%$.

Table 5. Group statistics

\begin{tabular}{lllll}
\hline & VAR00001 & $\mathrm{N}$ & Mean & Std. Deviation \\
\hline $\begin{array}{l}\text { Fixed assetsto1.00 } \\
\text { totalassets }\end{array}$ & 2.00 & 21 & .7178 & .17461 \\
$\begin{array}{l}\text { ratio } \\
\text { rayyyy}\end{array}$ & 21 & .4217 & .20781 \\
\hline
\end{tabular}

Table 6 shows that the value of independent samples Levene's Test is not significant at 5\% level. 
Table 6. Independent samples test

\begin{tabular}{|c|c|c|c|c|c|c|c|c|c|c|}
\hline \multicolumn{7}{|c|}{ t-test for Equality of Means } & \multicolumn{2}{|c|}{$\begin{array}{l}\text { Levene's Test } \\
\text { for Equality } \\
\text { of Variances }\end{array}$} & & \\
\hline \multicolumn{2}{|c|}{$\begin{array}{l}95 \% \text { Confidence } \\
\text { Interval of the } \\
\text { Difference }\end{array}$} & \multirow{2}{*}{$\begin{array}{l}\text { Std. Error } \\
\text { Difference }\end{array}$} & \multirow{2}{*}{$\begin{array}{l}\text { Mean } \\
\text { Difference }\end{array}$} & \multirow{2}{*}{$\begin{array}{l}\text { Sig. } \\
\text { (2-tailed) }\end{array}$} & \multirow[b]{2}{*}{ df } & \multirow[b]{2}{*}{$\mathrm{t}$} & \multirow[b]{2}{*}{ Sig. } & \multirow[b]{2}{*}{$\mathrm{F}$} & & \\
\hline Upper & Lower & & & & & & & & & \\
\hline 0.41582 & 0.17639 & 0.05923 & 0.29611 & 0 & 40 & 4.999 & 0.22 & 1.553 & $\begin{array}{l}\text { Equal } \\
\text { variances } \\
\text { assumed }\end{array}$ & \multirow{2}{*}{$\begin{array}{l}\text { Fixed } \\
\text { assetsto } \\
\text { totalassets } \\
\text { ratio }\end{array}$} \\
\hline 0.41593 & 0.17628 & 0.05923 & 0.29611 & 0 & 38.846 & 4.999 & & & $\begin{array}{l}\text { Equal } \\
\text { variances } \\
\text { not } \\
\text { assumed }\end{array}$ & \\
\hline
\end{tabular}

So we accept the null hypothesis so there is no difference in fixed assets to total assets ratio between Palestinian listed companies that have high sales on asset and Palestinian listed companies that have low sales on asset.

\subsection{Fixed Assets to Equity Ratio According to the Variable Return on Asset}

\subsubsection{Descriptive Statistics}

In Table 7 can be seen that the mean of Fixed assets to equity ratio equal $61.1 \%$. The maximum value equal $115 \%$, this value for Palestine Plastic Industries LADAEN in the Industry Sector. And the Minimum value equal $7 \%$ this value for The Vegetable Oil Industries VOIC in the Industry Sector.

Table 7. Descriptive

\begin{tabular}{|c|c|c|}
\hline & & Statistic \\
\hline \multicolumn{2}{|c|}{ Fixed assets toMean } & .6111 \\
\hline \multirow[t]{5}{*}{ equity ratio } & Std. Deviation & .28940 \\
\hline & Minimum & .07 \\
\hline & Maximum & 1.15 \\
\hline & Skewness & .330 \\
\hline & Kurtosis & -.901 \\
\hline
\end{tabular}

\subsubsection{Normality Test}

Normality test was conducted using Kolmogorov-Smirnovand Shapiro-Wilk the results in Table 8 showed that the data follow a normal distribution according to Shapiro-Wilk

Table 8. Tests of normality

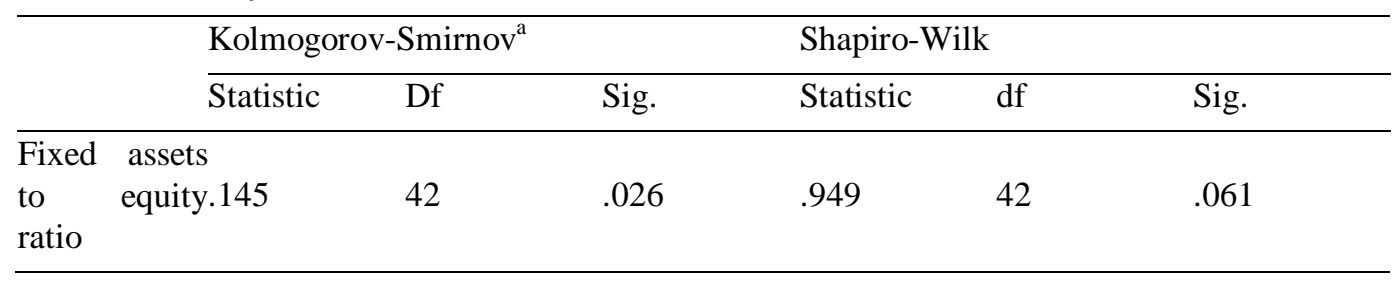




\subsubsection{Independent Samples Test}

The variable fixed assets to equity ratio arrangement according to the variable return on asset from the least to the greatest. From the Table9, we notice that the mean of the first group equal $73.2 \%$ with a Standard deviation equal $21.7 \%$. The mean of the second group $48.9 \%$.

Table 9

\begin{tabular}{lclll}
\hline & VAR00001 & $\mathrm{N}$ & Mean & Std. Deviation \\
\hline Fixed assets & to1.00 & 21 & .7322 & .21754 \\
\cline { 2 - 5 } equity ratio & 2.00 & 21 & .4899 & .30586 \\
\hline
\end{tabular}

Table 10 shows that the value of independent samples Levene's Test is not significant at $5 \%$ level.

Table 10. Independent samples test

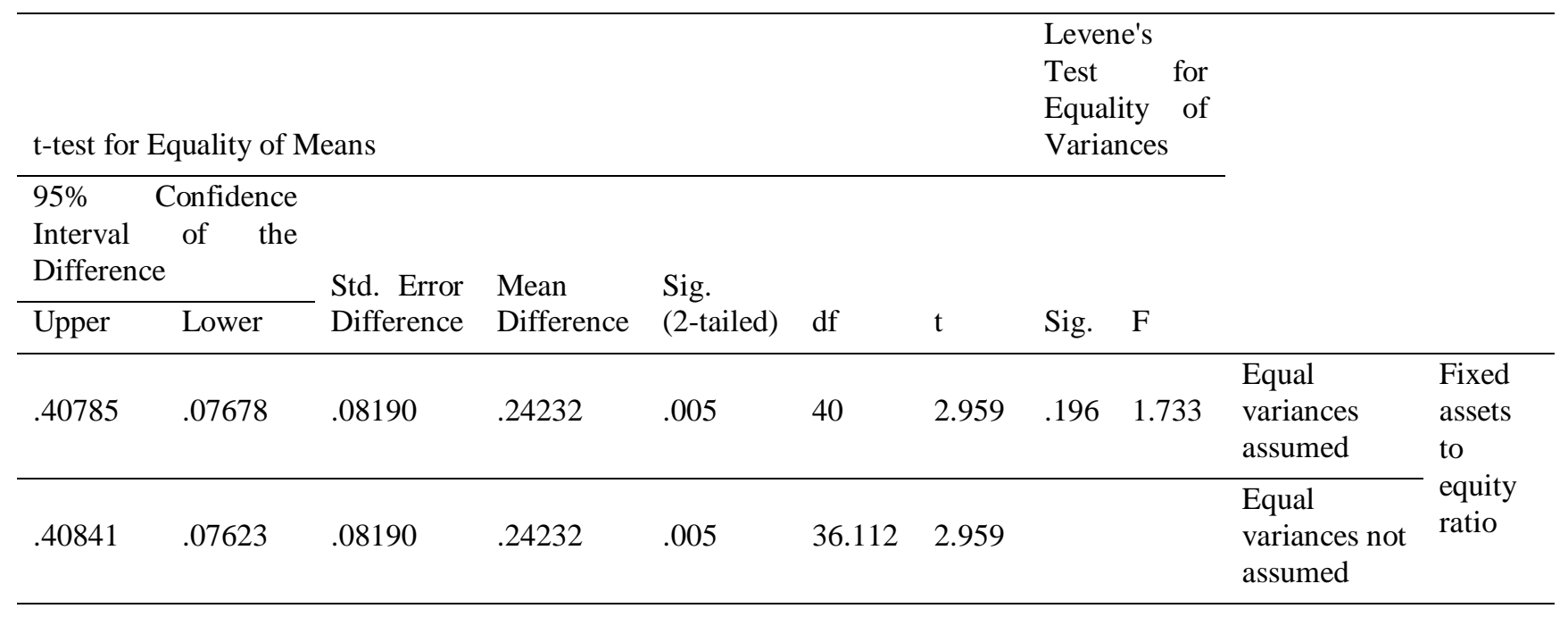

So we accept the null hypothesis so there is no difference in fixed assets to equity ratio between Palestinian listed companies that have high return on asset and Palestinian listed companies that have low return on asset.

4.6 Fixed Assets to Equity Ratio According to the Variable Sales on Asset

\subsubsection{Independent Samples Test}

The variable fixed assets to equity ratio arrangement according to the variable sales on asset from the least to the greatest. From the Table 11 we notice that the mean of the first group equal $81.7 \%$ with a Standard deviation equal $22.9 \%$. The meanof thesecond group $42.7 \%$.

Table 11

\begin{tabular}{lclll}
\hline & VAR00001 & $\mathrm{N}$ & Mean & Std. Deviation \\
\hline Fixed assets & to1.00 & 21 & .8173 & .22979 \\
\cline { 2 - 5 } equity ratio & 2.00 & 21 & .4272 & .21752 \\
\hline
\end{tabular}

Table 12 shows that the value of independent samples Levene's Testis not significant at $5 \%$ level. 
Table 12. Independent samples test

\begin{tabular}{|c|c|c|c|c|c|c|c|c|c|c|}
\hline \multicolumn{7}{|c|}{ t-test for Equality of Means } & \multicolumn{2}{|c|}{$\begin{array}{l}\text { Levene's Test } \\
\text { for Equality of } \\
\text { Variances }\end{array}$} & & \\
\hline \multicolumn{2}{|c|}{$\begin{array}{l}95 \% \text { Confidence } \\
\text { Interval of the } \\
\text { Difference }\end{array}$} & \multirow{2}{*}{$\begin{array}{l}\text { Std. Error } \\
\text { Difference }\end{array}$} & \multirow{2}{*}{$\begin{array}{l}\text { Mean } \\
\text { Difference }\end{array}$} & \multirow{2}{*}{$\begin{array}{l}\text { Sig. } \\
\text { (2-tailed) }\end{array}$} & \multirow[b]{2}{*}{ df } & \multirow[b]{2}{*}{$\mathrm{t}$} & \multirow[b]{2}{*}{ Sig. } & \multirow[b]{2}{*}{$\mathrm{F}$} & & \\
\hline Upper & Lower & & & & & & & & & \\
\hline 0.52967 & 0.25057 & 0.06905 & 0.39012 & 0 & 40 & 5.65 & 0.432 & 0.629 & $\begin{array}{l}\text { Equal } \\
\text { variances } \\
\text { assumed }\end{array}$ & \multirow{2}{*}{$\begin{array}{l}\text { Fixed } \\
\text { assets } \\
\text { to } \\
\text { equity } \\
\text { ratio }\end{array}$} \\
\hline 0.52968 & 0.25056 & 0.06905 & 0.39012 & 0 & 39.88 & 5.65 & & & $\begin{array}{l}\text { Equal } \\
\text { variances not } \\
\text { assumed }\end{array}$ & \\
\hline
\end{tabular}

So we accept the null hypothesis so there is no difference in fixed assets to equity ratio between Palestinian listed companies that have high sales on asset and Palestinian listed companies that have low sales on asset.

\section{Results-Post Crisis}

\subsection{Fixed Assets to Total Assets Ratio According to the Variable Return Onasset}

\subsubsection{Descriptive Statistics}

In Table 13 can be seen that the mean of total assets ratio equal 58.5\%. The maximum value equal $99 \%$, this value for Arab Investors ARAB in 2010. And the Minimum value equal 15\% this value for Jerusalem Cigarette JCC in 2011.

Table 13. Descriptive

\begin{tabular}{lll}
\hline Fixed assets to total assets ratio & \multicolumn{1}{c}{ Sean } & .5858 \\
\cline { 2 - 3 } & Std. Deviation & .22303 \\
\cline { 2 - 2 } Minimum & .15 \\
\cline { 2 - 2 } Maximum & .99 \\
\cline { 2 - 2 } & Skewness & -.121 \\
\cline { 2 - 2 } & Kurtosis & -.500 \\
\hline
\end{tabular}

\subsubsection{Normality Test}

Normality test was conducted using Kolmogorov-Smirnov and Shapiro-Wilk the results in Table 14 showed that the data follow a normal distribution.

Table 14. Tests of normality

\begin{tabular}{lllllll}
\hline & \multicolumn{3}{l}{ Kolmogorov-Smirnov $^{\mathrm{a}}$} & \multicolumn{4}{l}{ Shapiro-Wilk } \\
\cline { 2 - 7 } & Statistic & Df & Sig. & Statistic & df & Sig. \\
\hline Fx to at & .077 & 42 & $.200^{*}$ & .971 & 42 & .361 \\
\hline
\end{tabular}




\subsubsection{Independent Samples Test}

The variable fixed assets to total assets ratio arrangement according to the variable return on asset from the least to the greatest. From the Table 15 we notice that the mean of the first group equal $63 \%$ with a Standard deviation equal $17.7 \%$. The mean of the second group 54\%.

Table 15

\begin{tabular}{lllll}
\hline & VAR00001 & $\mathrm{N}$ & Mean & Std. Deviation \\
\hline Fixed & assetsto1.00 & 21 & .6308 & .17738 \\
\cline { 2 - 5 } totalassets ratio & 2.00 & 21 & .5408 & .25739 \\
\hline
\end{tabular}

Table 16 shows that the value of independent samples Levene's Test Test is significant at $5 \%$ level.

Table 16. Independent samples test

\begin{tabular}{|c|c|c|c|c|c|c|c|c|c|c|}
\hline \multicolumn{7}{|c|}{$\mathrm{t}$-test for Equality of Means } & \multicolumn{2}{|c|}{$\begin{array}{l}\text { Levene's Test } \\
\text { for Equality of } \\
\text { Variances }\end{array}$} & & \\
\hline \multicolumn{2}{|c|}{$\begin{array}{l}95 \% \text { Confidence } \\
\text { Interval of the } \\
\text { Difference }\end{array}$} & \multirow{2}{*}{$\begin{array}{l}\text { Std. Error } \\
\text { Difference }\end{array}$} & \multirow{2}{*}{$\begin{array}{l}\text { Mean } \\
\text { Difference }\end{array}$} & \multirow{2}{*}{$\begin{array}{l}\text { Sig. } \\
\text { (2-tailed) }\end{array}$} & \multirow[b]{2}{*}{$\mathrm{df}$} & \multirow[b]{2}{*}{$\mathrm{t}$} & \multirow[b]{2}{*}{ Sig. } & \multirow[b]{2}{*}{$\mathrm{F}$} & & \\
\hline Upper & Lower & & & & & & & & & \\
\hline 0.2279 & -0.04782 & 0.06821 & 0.09004 & 0.194 & 40 & 1.32 & 0.017 & 6.231 & $\begin{array}{l}\text { Equal } \\
\text { variances } \\
\text { assumed }\end{array}$ & \multirow{2}{*}{$\begin{array}{l}\text { Fixed } \\
\text { assetsto } \\
\text { totalassets } \\
\text { ratio }\end{array}$} \\
\hline 0.22845 & -0.04837 & 0.06821 & 0.09004 & 0.195 & 35.5 & 1.32 & & & $\begin{array}{l}\text { Equal } \\
\text { variances } \\
\text { not } \\
\text { assumed }\end{array}$ & \\
\hline
\end{tabular}

So we reject the null hypothesis and accept the alternative hypothesis so there is difference in fixed assets to total assets ratio between Palestinian listed companies that have high return on asset and Palestinian listed companies that have low return on asset.

\subsection{Fixed Assets to Total Assets Ratio According to the Variable Sales on Asset}

The variable fixed assets to total assets ratio arrangement according to the variable sales on asset from the least to the greatest. From the Table 17 we notice that the mean of the first group equal $68.1 \%$ with a standard deviation equal $19.5 \%$. The mean of the second group $48 \%$.

Table 17

\begin{tabular}{lclll}
\hline & VAR00001 & $\mathrm{N}$ & Mean & Std. Deviation \\
\hline Fixed & assetsto1.00 & 21 & .6815 & .19544 \\
\cline { 2 - 5 } totalassets ratio & 2.00 & 21 & .4853 & .20500 \\
\hline
\end{tabular}

Table 18 shows that the value of independent samples Levene's Test is not significant at 5\% level. 
Table 18. Independent samples test

\begin{tabular}{|c|c|c|c|c|c|c|c|c|c|c|}
\hline \multicolumn{7}{|c|}{ t-test for Equality of Means } & \multicolumn{2}{|c|}{$\begin{array}{l}\text { Levene's Test } \\
\text { for Equality of } \\
\text { Variances }\end{array}$} & & \\
\hline \multicolumn{2}{|c|}{$\begin{array}{l}95 \% \text { Confidence } \\
\text { Interval of the } \\
\text { Difference }\end{array}$} & \multirow{2}{*}{$\begin{array}{l}\text { Std. Error } \\
\text { Difference }\end{array}$} & \multirow{2}{*}{$\begin{array}{l}\text { Mean } \\
\text { Difference }\end{array}$} & \multirow{2}{*}{$\begin{array}{l}\text { Sig. } \\
\text { (2-tailed) }\end{array}$} & \multirow[b]{2}{*}{ df } & \multirow[b]{2}{*}{$\mathrm{t}$} & \multirow[b]{2}{*}{ Sig. } & \multirow[b]{2}{*}{$\mathrm{F}$} & & \\
\hline Upper & Lower & & & & & & & & & \\
\hline 0.32114 & 0.07131 & 0.06181 & 0.19623 & 0.003 & 40 & 3.175 & 0.803 & 0.063 & $\begin{array}{l}\text { Equal } \\
\text { variances } \\
\text { assumed }\end{array}$ & \multirow{2}{*}{$\begin{array}{l}\text { Fixed } \\
\text { assetsto } \\
\text { totalassets } \\
\text { ratio }\end{array}$} \\
\hline 0.32115 & 0.0713 & 0.06181 & 0.19623 & 0.003 & 39.909 & 3.175 & & & $\begin{array}{l}\text { Equal } \\
\text { variances } \\
\text { not } \\
\text { assumed }\end{array}$ & \\
\hline
\end{tabular}

So we accept the null hypothesis so there is no difference in fixed assets to total assets between Palestinian listed companies that have high sales on asset and Palestinian listed companies that have low sales on asset.

\subsection{Fixed Assets to Equity Ratio According to the Variable Return on Asset}

\subsubsection{Descriptive Statistics}

In Table 19 can be seen that the mean of total assets ratio equal $72.7 \%$. The maximum value equal $139 \%$, this value for Palestine Development \& Investment PADICO in 2012. And the Minimum value equal 9\% this value for Birzeit Pharmaceuticals BPC in 2011.

Table 19

\begin{tabular}{lll}
\hline & & Statistic \\
\hline Fixed assets & toMean & .7274 \\
\cline { 2 - 3 } equity ratio & Std. Deviation & .32195 \\
\cline { 2 - 3 } & Minimum & .09 \\
\cline { 2 - 3 } & Maximum & 1.39 \\
\cline { 2 - 3 } & Skewness & .104 \\
\cline { 2 - 3 } & Kurtosis & -.641 \\
\hline
\end{tabular}

\subsubsection{Normality Test}

Normality test was conducted using Kolmogorov-Smirnov and Shapiro-Wilk the results in Table 20 showed that the data follow a normal distribution.

Table 20. Tests of normality

\begin{tabular}{|c|c|c|c|c|c|c|}
\hline & \multicolumn{3}{|c|}{ Kolmogorov-Smirnov ${ }^{\mathrm{a}}$} & \multicolumn{3}{|c|}{ Shapiro-Wilk } \\
\hline & Statistic & df & Sig. & Statistic & $\mathrm{df}$ & Sig. \\
\hline Fixed assets to equity ratio & .071 & 42 & $.200^{*}$ & .982 & 42 & .751 \\
\hline
\end{tabular}




\subsubsection{Independent Samples Test}

The variable fixed assets to to equity ratio arrangement according to the variable return on asset from the least to the greatest. From the Table 21 we notice that the mean of the first group equal $75.2 \%$ with a standard deviation equal $22.8 \%$. The mean of the second group $70 \%$.

Table 21

\begin{tabular}{|c|c|c|c|c|}
\hline & VAR00001 & $\mathrm{N}$ & Mean & Std. Deviation \\
\hline \multirow{2}{*}{$\begin{array}{l}\text { Fixed assets to } \\
\text { ratio }\end{array}$} & equity1.00 & 21 & .7525 & .22842 \\
\hline & 2.00 & 21 & .7023 & .39872 \\
\hline
\end{tabular}

Table 22 shows that the value of independent samples Levene's Test is significant at $5 \%$ level.

Table 22

\begin{tabular}{|c|c|c|c|c|c|c|c|c|c|c|}
\hline \multicolumn{7}{|c|}{ t-test for Equality of Means } & \multicolumn{2}{|c|}{$\begin{array}{l}\text { Levene's Test } \\
\text { for Equality of } \\
\text { Variances }\end{array}$} & & \\
\hline \multicolumn{2}{|c|}{$\begin{array}{l}95 \% \text { Confidence } \\
\text { Interval of the } \\
\text { Difference }\end{array}$} & \multirow{2}{*}{$\begin{array}{l}\text { Std. Error } \\
\text { Difference }\end{array}$} & \multirow{2}{*}{$\begin{array}{l}\text { Mean } \\
\text { Difference }\end{array}$} & \multirow{2}{*}{$\begin{array}{l}\text { Sig. } \\
\text { (2-tailed) }\end{array}$} & \multirow[b]{2}{*}{ df } & \multirow[b]{2}{*}{$\mathrm{t}$} & \multirow[b]{2}{*}{ Sig. } & \multirow[b]{2}{*}{$\mathrm{F}$} & & \\
\hline Upper & Lower & & & & & & & & & \\
\hline 0.25294 & -0.15239 & 0.10027 & 0.05028 & 0.619 & 40 & 0.501 & 0.013 & 6.705 & $\begin{array}{l}\text { Equal } \\
\text { variances } \\
\text { assumed }\end{array}$ & \multirow{2}{*}{$\begin{array}{l}\text { Fixed } \\
\text { assets } \\
\text { to } \\
\text { equity } \\
\text { ratio }\end{array}$} \\
\hline 0.25457 & -0.15401 & 0.10027 & 0.05028 & 0.62 & 31.851 & 0.501 & & & $\begin{array}{l}\text { Equal } \\
\text { variances } \\
\text { not } \\
\text { assumed }\end{array}$ & \\
\hline
\end{tabular}

So we reject the null hypothesis and accept the alternative hypothesis so there is difference in fixed assets to equity ratio between Palestinian listed companies that have high return on asset and Palestinian listed companies that have low return on asset.

\subsection{Fixed Assets to Equity Ratio According to the Variable Sales on Asset}

The variable fixed assets to total assets ratio arrangement according to the variable sales on asset from the least to the greatest. From the Table 23 we notice that the mean of the first group equal $86 \%$ with a standard deviation equal $29.3 \%$. The mean of the second group $55 \%$.

Table 23

\begin{tabular}{|c|c|c|c|c|c|}
\hline & & VAR00001 & $\mathrm{N}$ & Mean & Std. Deviation \\
\hline \multirow{2}{*}{$\begin{array}{l}\text { Fixed } \\
\text { ratio }\end{array}$} & assets to & equity 1.00 & 21 & .8601 & .29310 \\
\hline & & 2.00 & 21 & .5507 & .34705 \\
\hline
\end{tabular}

Table 24 shows that the value of independent samples Levene's Test is not significant at $5 \%$ level. 
Table 24. Independent samples test

\begin{tabular}{|c|c|c|c|c|c|c|c|c|c|c|}
\hline \multicolumn{7}{|c|}{ t-test for Equality of Means } & \multicolumn{2}{|c|}{$\begin{array}{l}\text { Levene's Test } \\
\text { for Equality of } \\
\text { Variances }\end{array}$} & & \\
\hline \multicolumn{2}{|c|}{$\begin{array}{l}95 \% \text { Confidence } \\
\text { Interval of the } \\
\text { Difference }\end{array}$} & \multirow{2}{*}{$\begin{array}{l}\text { Std. Error } \\
\text { Difference }\end{array}$} & \multirow{2}{*}{$\begin{array}{l}\text { Mean } \\
\text { Difference }\end{array}$} & \multirow{2}{*}{$\begin{array}{l}\text { Sig. } \\
\text { (2-tailed) }\end{array}$} & \multirow[b]{2}{*}{$\mathrm{df}$} & \multirow[b]{2}{*}{$\mathrm{t}$} & \multirow[b]{2}{*}{ Sig. } & \multirow[b]{2}{*}{$\mathrm{F}$} & & \\
\hline Upper & Lower & & & & & & & & & \\
\hline 0.50969 & 0.109 & 0.09913 & 0.30935 & 0.003 & 40 & 3.121 & 0.549 & 0.366 & $\begin{array}{l}\text { Equal } \\
\text { variances } \\
\text { assumed }\end{array}$ & \multirow{2}{*}{$\begin{array}{l}\text { Fixed } \\
\text { assets } \\
\text { to } \\
\text { equity } \\
\text { ratio }\end{array}$} \\
\hline 0.50987 & 0.10883 & 0.09913 & 0.30935 & 0.003 & 38.91 & 3.121 & & & $\begin{array}{l}\text { Equal } \\
\text { variances } \\
\text { not } \\
\text { assumed }\end{array}$ & \\
\hline
\end{tabular}

So we accept the null hypothesis so there is no difference in fixed assets to equity ratio between Palestinian listed companies that have high sales on asset and Palestinian listed companies that have low sales on asset.

\section{Conclusion}

The findings showed that the average ratio of fixed assets to the total assets in the sectors of industry and investment rose from $56.2 \%$ prior to the crisis to $58.5 \%$ after the crisis. This rise constitutes a negative impact on working capital management. The fluctuation in this percentage was $23 \%$ in the pre-crisis period and then it declined after the crisis to $22 \%$. ARAB INVESTORS got the highest percentage, $99 \%$, and this paused danger to the company's liquidity.

As for the first hypothesis which is about the pre-crisis period, the results demonstrated that there a statistically significant different in the ratio of fixed assets to total assets between the listed companies that have high return on assets and those with low return. The percentage of low-return companies was 65\% compared high-return companies whose percentage was $46.7 \%$. based on this the researcher recommends reducing the percentage to $50 \%$ which in turn helps maintain the percentage of current assets so that they work more effectively. As for the second hypothesis, the results showed that there is a statistically significant difference in the percentage of fixed assets to total assets between firms with high return on sales and those with low return. The ratio of fixed assets to total assets was high, $71.7 \%$. Whereas the companies with high return on sales, the ratio of fixed assets to total assets was low. The researcher recommends reducing the percentage to $50 \%$ to maintain the percentage of current assets and thus operate more effectively.

The results showed the average ratio of fixed assets to equity rights for the sectors of industry and investment rose from $61.1 \%$ to $72 \%$ after the crisis. Palestine Plastic Industries LADEN came first, $115 \%$. Concerning the third and fourth hypotheses, the findings showed that there is no statistically significant difference in the ration of fixed assets to equity rights.

Regarding the hypotheses in the post-crisis period, the results showed no difference except for the seventh hypothesis. Here the findings demonstrated a statistically significant difference in the ratio of fixed assets to equity rights between the listed companies with high return on assets and those listed ones with low return. The ratio of fixed assets to equity rights for low-return companies did not exceed $75 \%$ compared to high-return companies whose ratio was $70 \%$. Therefore the researcher recommends reducing the ratio of fixed assets to equity rights to increase profits.

\section{Acknowledgement}

The researcher thanks Palestine Technical University- kadoorie for its constant moral and financial support for this research as well as scientific research in general. 


\section{References}

Çelikand Boyacioğlu. (2013). The impact of fixed assets expenditures on working capital management: an application on manufacturing enterprises in Istanbul stock exchange. Journal of Süleyman Demirel University Institute of Social Sciences, (17), 81-98.

Dong, et al.. (2012). What drives fixed asset holding and risk-adjusted performance of corporates in China? An empirical analysis. International Real Estate Review, 15(2), 141-164.

Eriotis, et al.. (2014). Profit margin and capital structure: An empirical relationship. The Journal of Applied Business Research, 18(2), 85-88. https://doi.org/10.19030/jabr.v18i2.2118

Iqbal, M. (2013). Relationship between non-current assets \& firms protability. MPRA Paper No. 44132.

Lazăr, L. (2012). The impact of the economic crisis on the evolution of tangible fixed assets in Romania. Economic Insights - Trends and Challenges, I(3), 47-56.

Mohammadzadeh, et al.. (2014). Study the relationship between dividend yield and investments in fixed assets of active companies in Tehran stock exchange. Kuwait Chapter of Arabian Journal of Business and Management Review, 3(11), 219-225. https://doi.org/10.12816/0018799

Okwo, O. (2012). Investment in fixed assets and firm profitability: evidence fromthe Nigerian brewery industry. European Journal of Business and Management, 4(20), 10-17.

Olatunji, A. (2014). Investment in fixed assets and firm profitability: empirical evidence from the Nigerian banking sector. Asian Journal of Social Sciences and Management Studies, 1(3), 78-82.

Qumsan, A. (2005). Analytical study of the reality of the Palestinian economy between investment opportunities and challenges of the future. Working paper submittedto theFirst Scientific Conference.

Sabri, T., \& Sweis, K. (2016). Effect of corporate social responsibility on profitability of banks working in Palestine (case study 2013-2014). International Journal of Business Administration, 7(6), 107-114. https://doi.org/10.5430/ijba.v7n6p107

\section{Copyrights}

Copyright for this article is retained by the author(s), with first publication rights granted to the journal.

This is an open-access article distributed under the terms and conditions of the Creative Commons Attribution license (http://creativecommons.org/licenses/by/4.0/). 